\title{
Uneasy Neighbors: Turkish-Iranian Relations Since the 1979 Islamic Revolution
}

\author{
Nihat Ali Özcan / Özgür Özdamar
}

\author{
Dr. Özcan is a researcher at the Economic Policy Research Institute and an \\ instructor at the TOBB University of Economics and Technology, and Dr. \\ Özdamar is an assistant professor at Bilkent University, both in Ankara.
}

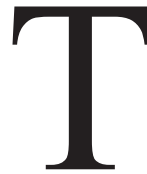

urkey and Iran have for centuries maintained an uneasy relationship of conflict and cooperation, shaping the history of the Middle

East. This article focuses particularly on the development of the relationship since the 1979 Islamic Revolution in Iran. The analysis shows that the Turkish-Iranian relationship can be described as a "structural regional rivalry" whose intensity and issues are determined by conjectural changes at the systemic and sub-systemic levels. Although the historical analysis shows a tendency for rivalry, there have been occasional opportunities for close cooperation, such as the rapprochement since the early $2000 \mathrm{~s}$. To account for the dynamics that produce either cooperation or conflict, we first analyze historical processes and the changing factors that have shaped the relationship. Then we turn to the post-revolutionary period and the factors that produced economic cooperation from 1979 to 1988 , rivalry and conflict from 1988 to 2002, and rapprochement since 2002. The analysis shows that, although the long-term nature of Turkish-Iranian relations is one of rivalry, when certain factors emerge, the two neighbors can engage in close cooperation.

\section{CONSTANTS}

Six factors have shaped the course of relations between Turkey and Iran since the sixteenth century. The first is geopolitics. ${ }^{1}$ Both countries' vast territories allowed them to exert influence on the Middle East, Central Asia and the Caucasus. They both have been considered "gateways" to Central Asia and the Caucasus and have been major actors in the Middle East. Iran's geography appeared to be an advantage in influencing both Mus$\lim$ (especially Shia) and non-Muslim nations in Central Asia and the Caucasus and in controling oil-rich regions such as the Persian Gulf. Similarly, Turkey's eastern border connects it to historically important trade routes across Asia, and the country is strategically located around five major seas that are vital for trade and energy transportation: the Caspian, Black, Marmara, Aegean and Mediterranean. ${ }^{2}$ These advantages had their downsides. Iran became a playground for great-power politics during the nineteenth and the first half of the twentieth century, suffering from BritishRussian rivalry in and around Central Asia and the Middle East. Great-power politics of the period also weakened the Ottoman Middle East Policy (C) 2010, Middle East Policy Council 
Middle East Policy, Vol. XVII, No. 3, Fall 2010

Empire's control over its territories. Therefore, geopolitics created a natural rivalry between Turkey and Iran for control of the Middle East and Central Asia. ${ }^{3}$

The second recurring pattern in Turkish-Iranian relations concerns ethnic minorities. Both countries are multi-ethnic in character and include similar ethnic groups, such as Azeris and Kurds. Iran's Azeris are estimated to constitute more than 25 percent of the population, while about 15 percent of the population of Turkey is Kurdish. ${ }^{4}$ Iran was ruled by minority Turkic dynasties from the early sixteenth to the twentieth century, ${ }^{5}$ and even after the establishment of Persian control, Iran has maintained caution about potential irredentism from the Azeri minority in the north. In Turkey, after the collapse of the Ottoman Empire, Kurds became the largest minority; they revolted against the central government at various times in the 1920s, 1930s and 1980s. Iran's minorities also include Kurds on the western border, as well as Arabs, Gilaki, Mazandarani, Baloch, Turkmen and some Christians. The Ottoman Empire claimed that Iran helped its Armenian population to revolt during the late nineteenth and early twentieth centuries. ${ }^{6}$ In addition, the empire always feared Iran's influence on groups such as Shia, Alevi or Qizilibash in Turkey.

The third issue is the significant cultural divide between the two countries. Each one championed the leadership of a major sect of Islam during the period of the Ottoman and Safavid empires. A competition for leadership of the Muslim world was one of the determining factors in their relations, generating a series of diplomatic competitions and military conflicts beginning in the sixteenth century. ${ }^{7}$ At the peak of these conflicts, the Ottoman Sultan, Selim I, defeated the Safavids in 1514.
During the nineteenth century, nationalism also was a major problem between the two countries. Pan-Turkism has always been a source of worry for Iran, due to the large number of Azeris and other Turkic peoples within the country. For example, the Young Turk movement's pan-Turkism in the early twentieth century was a major source of confrontation between the two countries. Similarly, when the Soviet Union dissolved during the 1990s, Iran's policy makers feared separatist movements among the country's Azeri population. Each country has been suspicious of the others meddling with its minorities and promotion of its religion or nationality in the region.

Over the centuries, political and ideological rivalries have been related to the cultural divides between Iran and Turkey. From the sixteenth to the twentieth century, Shia Safavids and Qajars in Iran and Sunni Ottomans competed for the leadership of the Muslim world. Pan-Turkist movements in the early twentieth century were a nightmare for Iranians, while the Pan-Islamism of the Young Turks received mixed reactions among the Iranian elite. ${ }^{8}$ Ottoman Sultan Abdulhamid II's efforts to arouse the Shia clergy (Mujahedin) in Iraq against the Iranian regime and his aspiration to unite the Muslim world under Ottoman rule were not welcomed by Iran's rulers. After constitutional revolutions in Iran (1905) and Turkey (1908), the two countries took different paths in their regime choices. The young Turkish Republic tried unsuccessfully to influence Reza Shah Pahlavi to establish republican rule in Iran. The founder of modern Turkey, Kemal Atatürk, articulated his disappointment that the shah chose dynasty instead of a republic in $1925 .{ }^{9}$

The two countries maintained rather friendly relations under shah's regime, although they presented two different 
models to the Muslim world. While Iran pursued modernization under an authoritarian monarch, Turkey modernized its economy and social life and established a multi-party democracy after 1946. During World War II, Iran was occupied by the Allies, while Turkey managed to stay neutral. After the war, Turkey joined the Western alliance, and Iran maintained a balance between Western and Eastern blocs until the late 1960s. During the 1970s, Shah Muhammad Reza Pahlavi pursued a proAmerican foreign policy, which came to an abrupt end with the Islamic Revolution. Iran's breaking its ties with the Western world and NATO exacerbated the ideological divide between the two countries, given Turkey's position in NATO. Turkey's secular elite suspected the Iranian revolutionaries' aspirations to promote similar Islamist movements in the region. ${ }^{10}$ Iran, on the other hand, blamed Turkey for harboring Iranian refugees, whose number was estimated at 600,000 to 1 million. These were allegedly members of the Mujahedin-elKhalq, a dissident group that opposed the mullah regime, as well as other pro-shah armed groups in Turkey. ${ }^{11}$

Thus, Turkey and Iran found themselves once again on opposite sides of a political dispute during the last two decades of the twentieth century, a period in which the military control of the Turkish polity was at its peak, exacerbating the ideological conflict with Iran. ${ }^{12}$ In their regional competition, Turkey presented itself as a successful example of secularism and democracy, while Iran considered itself the champion of Islamism.

Border problems have also been significant sources of confrontation. Today's border was, to a great extent, determined in 1639 by the Kasr-1 Şirin agreement between the Ottomans and Safavids. ${ }^{13}$
There is a common belief in Turkish public opinion that, since there have been no major wars between the two countries in the last three centuries, border problems also do not exist. In reality, the two countries have engaged in armed conflicts many times since 1639 , and there were some serious border problems. For example, in 1930, during a Kurdish rebellion in Ağr1, a province in eastern Turkey, the Turkish government protested that the rebels were given free passage from the Iranian border. ${ }^{14}$ Turkey and Iran signed a formal agreement that changed the border in 1931, making it easier for Turkey to protect. ${ }^{15}$

A sixth durable factor consists of the economic ties and trade between the two countries. Turkey and Iran began the twentieth century with similar underdeveloped, pre-industrial economies and agrarian societies. Under Shah Mohammed Reza's White Revolution, Iran achieved impressive economic reforms and high growth, fueled by the country's vast petroleum resources during the 1960s and 1970s. Iran was considered to be an economic success in the region. During the same period, Turkey maintained an import-substitution growth strategy, which seemed less successful. However, in the early 1980s, Turkey initiated liberal reforms and pursued an exportoriented growth, which brought substantial economic expansion, especially in the 2000 s. In the 1980s, during the war with Iraq, Iran depended on imports from Turkey, paid for by oil. Since the mid-1990s, Turkey and Iran have signed a series of agreements on energy transportation from Iran to Turkey and other European markets.

\section{VARIABLES}

In addition to the six durable factors shaping relations between the two countries over the past half millennium, important 
Middle East Policy, Vol. XVII, No. 3, Fall 2010

variables must be considered. For example, superpower penetration into the region has changed the nature of the Turkish-Iranian rivalry. Beginning in the early 1800 s, Britain and Russia were involved in the so-called Great Game for the control of Central Asia. This rivalry shaped the threat perception of Iranian policy makers. With imperial Britain and Russia in the region, the Ottoman Empire seemed a lesser threat to Iranians - and vice versa. ${ }^{16}$ Such changes in threat perception, however, did not cause a rapprochement between Iran and Turkey. They continued to undermine each other's sovereignty and play the superpowers against each other. Iran's support for Armenian independence during the late nineteenth century, along with Russian attempts to gain advantages over Turkey during the Berlin conference of 1878 and through the Sèvres Treaty of 1920, are some examples. ${ }^{17}$

Relations with great powers have been decisive in two different ways. In some instances, great-power politics caused rapprochement between Turkey and Iran, as during the Cold War, when they were members of the Central Treaty Organization (CENTO). ${ }^{18}$ At other times, greatpower involvement sharpened the rivalry, as has occurred in Central Asia during the post-Cold War era. The most serious crisis in the relationship was brought about by the Islamic Revolution in 1979, which completely changed Iran's priorities and alliances. In its post-revolutionary foreign policy, Iran tried to influence Shia groups to spread the Islamic Revolution across the
Middle East, engaged in a prolonged war with Iraq, and destroyed its former cordial relations with the United States and Israel. These developments, of course, diminished the importance of the "Turkish threat" for Iran. The new regime's threat perception of Turkey was diminished.

When the USSR collapsed, Iran found itself in a very difficult international position. Being one of the few major challengers to the only superpower was not easy. The United States not only challenged Iran on various issues in the region, it also supported Turkey and the "Turkish model" as a secular, modern Muslim country against the Islamic regime. ${ }^{19}$ Iran was regularly excluded from gas and oil projects, and Turkey was supported. Washington also maintained pressure on Iran (and Iraq) with the implementation of a policy of "dual containment." 20 These developments led Iran to pursue better relations with Russia. ${ }^{21}$

Political changes in the Middle East, Central Asia and the Caucasus also appear to be important determinants of TurkishIranian relations in the post-revolution era. First, war with Iraq and isolation by the West led Iran to pursue better relations with Turkey in the 1980s on trade and other economic issues. During this period, Iran also supported non-state armed groups and terrorist organizations throughout the region and championed Islamism against Western governments, Israel and the secular-nationalist establishment in Middle Eastern states. ${ }^{22}$ Iran supported Hezbollah 
in Lebanon and the anti-Turkey actions of the Kurdistan Workers Party (PKK) in Northern Iraq in the early 1980 s. $^{23}$ On the other side of the border, about a million Iranians who had fled the country after the revolution used Turkey for safe passage to Europe and the United States. At the regional level, an Iran-Syria alliance that began in the early 1980s was balanced by Turkish-Israeli cooperation in military, security and economic matters in the 1990s. ${ }^{24}$

During the 1990s, the instability caused by the emergence of the newly independent states in the Caucasus and Central Asia also contributed to TurkishIranian rivalry. Turkey presented itself as a model in terms of democratization and liberal economy, while Iran promoted an image that combined religious and ideological factors, as well as some economic benefits. ${ }^{25}$ The political shifts of the early 2000s brought both risks and opportunities to Iran. On the one hand, its staunch enemies, the Taliban and Saddam Hussein, were both toppled by the United States. However, these changes also led Iranian policy makers to perceive the United States as an even greater threat. The Iraq War also exacerbated Turkish-American relations because the Turkish parliament voted against joining the U.S.-led coalition in March 2003. ${ }^{26}$

\section{POST-REVOLUTION RELATIONS}

With the end of the shah's regime, Iran's foreign policy took a significant turn, changing almost over night from a key Western ally into one of the fiercest challengers of American hegemony. This shift in Iran has redefined its relations with Turkey. In addition to the Sunni-Shia division, which was deemed particularly important by the mullahs, the foreignpolicy orientation of the two countries also diverged completely. While Iran has maintained contentious policies toward America and even Russia, Turkey continues to be part of the Western alliance, NATO and Europe. The revolution led America to redefine its alliances in the region and maintain even closer relations with Turkey. Despite the changing character of the state and its foreign policy, as well as ideological and religious differences, when faced with political and economic isolation and a bitter war with Iraq, Iran reluctantly turned to Turkey for economic and strategic connections.

\section{The Iran-Iraq War, 1980-88}

The first decade of Turkish-Iranian relations after the revolution was marked by the Iran-Iraq War and a willingness to cooperate in trade and economic relations. In fact, the initiative that started the relationship with the Islamic regime came from Turkey. On February 14, 1979, only three days after the Islamic Revolution's "victory day," Turkey recognized the new regime almost instantly. The new Iranian government saluted Turkey's recognition and announced that leaving CENTO would not weaken relations between the two countries. ${ }^{27}$ There were many reasons that Turkey acted so quickly to recognize Iran. First, Turkish Prime Minister Bülent Ecevit was a fierce critic of the shah's regime and the CENTO alliance. ${ }^{28}$ Second, Turkish policy makers have always been concerned about civil war and the possible disintegration of Iran, which might have led the USSR to intervene and might have precipitated Kurdish separatism at Turkey's eastern border. ${ }^{29}$ Also, Turkey foresaw that a weaker Iran could become a good trading partner. Turkey also realized that Iran's shift to an anti-Western posture would benefit Turkey in the long run. Turkey's 
Middle East Policy, Vol. XVII, No. 3, Fall 2010

first reaction to the Iranian Revolution was based on calculations about the regional rivalry between the two countries. However, Turkish policy makers have also been concerned about the weakened governmental structure in Iran, fearing instability.

Only one year after the revolution, in September 1980, the Iran-Iraq War began. For Iran, the war with Iraq to its west and the American presence in the Gulf made economic cooperation with Turkey a vital issue. Iran needed to use Turkish ports in the Black Sea and the Mediterranean for strategic imports in its war effort. It bought goods from Turkey in return for oil and gas in the early $1980 \mathrm{~s}^{30}$ For Turkey, trade with Iran was necessary to boost its own bankrupt economy. Such increased trade was in line with the liberal economic reforms in the early 1980s carried out by Prime Minister Turgut Özal. In this period, the volume of trade between the two countries exceeded $\$ 2$ billion, ${ }^{31}$ consisting mainly of oil sales by Iran in return for Turkish goods and technical assistance.

During the Iran-Iraq War, Turkey maintained a strict neutrality and improved its economic relations with both neighbors, especially Iran. ${ }^{32}$ Turkey's neutrality was welcomed in both Iran and the Arab world. However, when Turkey attempted to mediate the conflict, it did not succeed. Despite developments in trade relations, problems arose between Ankara and Tehran in the mid-1980s over PKK terrorism in Turkey and Iran's efforts to spread the Islamic Revolution in the region. As PKK attacks increased, Turkey conducted raids in Northern Iraq to pursue militants, claiming its operations were only for "hot pursuit" in line with international law. ${ }^{33}$ Iran protested Turkey's operations in Northern Iraq and voiced suspicions about its aims. On the other hand, Turkish policy makers were concerned about Iran's alliance with the Patriotic Union of Kurdistan (PUK) and the Kurdistan Democratic Party (KDP) and its support for the PKK. ${ }^{34}$

After the first half of the 1980s, Turkish-Iranian relations were marred by difficulties related to ideological differences. Iran, as the self-proclaimed world leader of Islam, repeatedly protested the secularist policies and Kemalist establishment in Turkey, including the headscarf ban in Turkish universities. ${ }^{35}$ Remarks by high-level Iranian officials caused protests from various actors in Turkey, including the social-democratic opposition party (SHP). For example, in January 1987, SHP chairman Erdal İnönü criticized Iranian officials for intervening in the domestic affairs of Turkey. ${ }^{36}$ The period of 1988-89 was a time of strained diplomatic relations and the recalling of the two countries' ambassadors.

During this period, regional political changes were also significant. Iran approached Syria, and an alliance between the two countries against the U.S. and Israel began in the early 1980s. With Iran's assistance, Syria helped establish anti-Israel organizations in Lebanon, such as Hezbol1ah. ${ }^{37}$ Such anti-Israeli policies and rhetoric increased the Iranian regime's legitimacy. By making use of anti-Israeli sentiments in the region and the Iraq-Syria competition, Iran effectively broke its isolation and was able to pursue its foreign policy. On the other hand, systemic factors in this period favored Turkey. The United States reacted to the Islamic Revolution by improving its relations with Turkey even more and sent its Rapid Deployment Force to the Persian Gulf to counter Iran. The United States also asked Turkey for military bases and transferred its intelligence stations from Iran to Turkey. As Iranian-U.S. relations 
worsened, Turkey appeared to be the most important ally of NATO and the United States in the region.

\section{The Post-Soviet Space, 1988-97}

Significant developments toward the end of the 1980s changed the regional dynamics as well as the course of IranTurkey relations. First, in 1988, after eight years of fierce fighting, the Iraq-Iran War ended in a status quo ante bellum, although both sides claim victory to this day. Iran's Supreme Leader Khomeini died in 1989, succeeded shortly afterward by Ali Khamanei. The end of the Cold War and the collapse of the USSR were the most important systemic changes affecting Turkey-Iran relations. In addition to the challenges caused by the Islamic Revolution, the constants of Turkey-Iran relations, in the form of cultural, political and ideological rivalries, rose to the surface. Turkey and Iran found themselves in competition for their influence over Central Asia and the South Caucasus.

The collapse of the USSR and the independence of Azerbaijan were difficult for Iranian officials to cope with. About a quarter of Iran's population are Azeris living in the north of the country, which is historically called southern Azerbaijan. An independent state of Azerbaijan was perceived as a serious threat to Iran's territorial integrity. Moreover, Iran realized the importance of spreading its influence in the post-Soviet space, especially in the newly independent Muslim Turkic states of Central Asia.

Turkey, as a NATO member and European Union aspirant, certainly found the new developments more beneficial for itself. Despite early fears that the end of the Cold War would diminish Turkey's strategic position in the region, Ankara quickly realized that there were new opportunities in the competition for influence. Turkey presented Central Asia with the so-called "Turkish model," emphasizing ethnic Turkic ties, secularism, integration into Western economic and political institutions, and increased trade and cultural ties. Turkey's success in the region was mixed. It did not appear to be the main influence in the regional rivalry; however, the pessimistic prediction that Turkey would become irrelevant and loose all ground to Russia and Iran did not come true, either. ${ }^{38}$ Turkey was successful in improving its relations, especially in Azerbaijan and Georgia, and has shown a significant presence in Turkmenistan, Kazakhstan and Kyrgyzstan.

The most important factor behind Turkey's success has been Western support for its increased role in Central Asia and the South Caucasus. A second major factor has been the U.S. policy of isolating Iran and promoting the Turkish model in order to limit Iranian and Russian influence. The United States supported Turkey's political, economic and military influence in these two regions. For example, Washington vehemently opposed the transport of Caspian oil and gas through Iran, instead supporting projects that would go through Turkey, and prevented countries like Georgia and Armenia from developing stronger economic and political ties with Iran. ${ }^{39}$

Iran, on the other hand, has attempted to create its own spheres of influence and alliances against Turkish-Western penetration into the region. From the early 1990s, Iran ceased the "small-Satan" rhetoric against Russia and developed closer ties with it against Turkey and the United States. Iran's approach to the Central Asian Turkic republics included promoting Islamic ideology, supporting Islamist movements and developing some economic relations through energy trade. This 
Middle East Policy, Vol. XVII, No. 3, Fall 2010

shifted the focus of Turkey-Iran competition from south to north.

The Gulf War of 1990-91 changed the dynamics in the region. After its invasion of Kuwait, Saddam Hussein's Iraq, one of the leading military powers in the region, controlled the world's second largest oil reserves. Iran and Turkey approached this crisis differently. Under the active leadership of President Turgut Özal, Turkey joined the international coalition. Özal considered that the Gulf War and the U.S. need to use Turkey's military bases presented a great opportunity to reassert Turkey's strategic position in the post-Cold War world. Iran, on the other hand, took a very pragmatic approach. Although some expected the Islamic Republic to support Iraq as an example of Muslim solidarity against the United States, Tehran preferred to stay neutral during a conflict that would weaken their greatest adversary in the region. Such developments also strengthened the loose alliances between Iran and Syria and Turkey and Israel. Turkish-Israeli cooperation in military technology and intelligence, which was strongly supported by the United States, was repeatedly protested by Iran and Syria.

Turkey's biggest worry following the Gulf War was PKK terrorism, which peaked in the 1992-95 period. By using the vacuum created by the United States and its allies north of the thirty-sixth parallel in Iraq, the PKK operated freely and conducted its largest attacks on Turkey. Ankara attempted to end Iranian and Syrian support for the PKK through diplomatic efforts, but these did not prove effective. Against Turkish-Azeri cooperation on energy transportation, Iran used the PKK card to destabilize the region, particularly its oil pipelines. PKK fighters were able to freely cross the Iraqi, Iranian and Syr- ian borders, making it very difficult for the Turkish armed forces to pursue them. Turkish incursions into northern Iraq, and occasionally Iranian territory, were condemned by the Iranian government. During the pursuit of PKK members, the Turkish forces carried out bombings at the TurkeyIran border, which caused protests by Iran. In July 1996, the activities of PKK guerrillas who crossed the Iranian border and attacked Turkish military posts led to a serious crisis between the two countries that could have turned into an armed conflict. ${ }^{40}$

Turkey, on the other hand, attempted to obtain support from Syria and Iran in its fight against the PKK. Exploiting concerns that an independent Kurdistan could cause Iraq to disintegrate, Turkey initiated threeparty talks with Iran and Syria to observe the situation in Iraq. These meetings reassured the three countries of their joint interest in the territorial unity of Iraq. During these meetings, Turkey also warned Iran about PKK activities in the region. However, full cooperation with Iran against the PKK was never achieved. On the contrary, Iran and Turkey engaged in a proxy war in Northern Iraq during this period. During the civil war between two principal Kurdish groups in Northern Iraq, Iran supported Jelal Talabani's PUK and the PKK, while Turkey supported Massoud Barzani's KDP against the other two. ${ }^{41}$ Turkey's incursions into Iraq, with 35,000 troops in 1995 and 50,000 in 1997, were condemned by Tehran. Iranian officials argued Turkey's invasions were not only a violation of international law, but the sovereign rights and territorial integrity of the Muslim Iraqi nation. When Turkey accused Iran of supplying bases, transportation, medicine, hospitals and uniforms, Iran denied the allegations and blamed them on the Turkish military, Israel and the United States. ${ }^{42}$ 
Finally, this period witnessed the exacerbation of ideological rivalries between the two countries. In the early 1990s, Turkey experienced the political murders of several journalists, opinion leaders, and other public figures, causing a huge stir in the country. These intellectuals were exclusively secularists and leftists who opposed Islamic political movements and Iran's policies in the region. The suspects in these assassinations had allegedly been trained in Iran. For example, on February 4, 1993, Minister of Internal Affairs İsmet Sezgin announced that the suspects of two high-profile assassinations were
The political chill started thawing during the tenure of the first Islamist prime minister of Turkey, Necmettin Erbakan, who visited Tehran during August 1996 and signed various economic agreements.
Turkish military bureaucracy ${ }^{44}$ Erbakan's tenure was too short to establish a sustainable change in the course of relations and failed to reconcile two countries' interests.

\section{Domestic Political Challenges, 1997-2002}

The Kurdish and Islamist questions continued to challenge Turkish-Iranian relations in the late 1990s and early 2000s. In fact, this period witnessed the worst of all crises in Turkish-Iranian relations since the revolution in 1979. In February 1997, the Turkish Armed Forces (TAF) pressured Islamist Prime Minister Erbakan to sign a National Security Council trained at a military base "located between Tehran and Qom" in Iran. ${ }^{43}$ The assassination of well-known journalist Uğur Mumcu in January 1993, which caused the largest public protests of its kind, was also allegedly connected to the Iranian state. Tehran repeatedly denied any connection to these assassinations and to date, connections between the Iranian government and the political assassinations of secular thinkers in Turkey have not been proven.

The political chill started thawing during the tenure of the first Islamist prime minister of Turkey, Necmettin Erbakan, who visited Tehran during August 1996 and signed various economic agreements. One of these included a naturalgas purchase of 10 million cubic meters (worth $\$ 23$ billion) effective until 2002. In December 1996, Turkey and Iran signed five new agreements concerning economic relations. The desire of Erbakan's government to extend cooperation to the military and defense sectors was opposed by the document aimed at fighting against "Islamist reactionary movements" operating in Turkey. Political developments in the following months led Erbakan to resign in June, and his Welfare Party (RP) was shut down by the courts the following year. This period in Turkish history, involving a power struggle between the secularist military and an Islamist prime minister, is called " the February 28 coup," or "the post-modern coup" by some academics. The military's influence on the domestic and international affairs of Turkey continued in the following years, although the secularist Y1lmaz and Ecevit governments succeeded that of Erbakan.

TAF influenced Turkey's defense and foreign policies to a great extent during this period, when its most serious international challenges were relations with Iran and Syria. The two gravest problems in Turkey - the Kurdish question and the Islamist challenge - were both related to Iran's policies..$^{45}$ Turkey's dissatisfac- 
tion with Iran's influence was not limited to the Kurdish matter. Iran was vilified by Turkish secularist and mainstream media because it allegedly supported Islamist movements and even the Kurdish Hezbollah that was operating in Turkey. ${ }^{46}$ An important example of Iran's becoming a locus of domestic political conflict in Turkey was a crisis that involved Iran's ambassador to Ankara, Mohammed Bagheri. He was asked to leave Turkey in 1997 after a speech in which he supported the Islamist movements in Turkey. He also promoted the establishment of an Islamist system in Turkey and openly criticized its secularism. In retaliation, Iran expelled the Turkish ambassador to Tehran the same year. ${ }^{47}$

The next crisis involved a female Islamist member of the Turkish parliament, Merve Kavakçı. Kavakçı attended a parliamentary session wearing a headscarf, which caused an uproar in secular circles. When the secularists protested against her, and she was not allowed to be sworn in, Islamist circles in Turkey were outraged. The Kavakçı affair continued for several months and became a focus of attention for the international press, including Iran's. The protests against Kavakçı were severely criticized by the Iranian media, and officials such as Foreign Minister Kamal Kharazi openly criticized secularism in Turkey. ${ }^{48}$ Iranian students in Tehran demonstrated for the freedom of Turkish women to wear the headscarf. During this period, the two countries' media engaged in a "war of bombast." Prime Minister Ecevit blamed Iran for trying to export its Islamic regime and continuing to support the PKK. ${ }^{49}$ Finally, the Turkish government's crackdown on an Islamist terrorist organization, the Kurdish Hezbollah, further worsened relations between the two countries. Turkish officials claimed that leaders of Hezbollah received political and military training from Iranian security and intelligence forces, worked as spies for the Iranian government and were involved in political killings in Turkey during the $1990 \mathrm{~s} .{ }^{50}$

The period from 1997 to 2000 witnessed perhaps the most tumultuous events in Turkish-Iranian relations for three decades. However, regional, systemic and domestic developments in 2000-02 led Iran to reduce tensions with Turkey. First, the political conflict among the Iranian elite in this period focused on Iran's domestic dynamics. On the other hand, PKK leader Abdullah Öcalan's expulsion from Syria in 1998 and his capture by Turkey in 1999 triggered a series of regionwide Kurdish demonstrations and unrest. All these events led Iranian policy makers to realize the PKK's influence on the Kurds in Iran. Fearing a general Kurdish movement in the region and a separatist one on its own soil, Iran decreased its support for the PKK significantly. Tehran became even more concerned after the 9/11 attacks and the possibility of an American invasion of Iraq because such an invasion, if carried out in cooperation with Turkey, would increase Turkey's control over Northern Iraq and diminish Iran's influence over regional politics. In addition, Iran realized that, as a result of 9/11, cooperation between Turkey and Israel and their relations with the United States had intensified. ${ }^{51}$ Also, increased military cooperation and Israel's growing military presence in Turkey reinforced worries in Tehran that this alliance could be used against Iran. Taking all these factors into account, Iran decided to suspend relations with the PKK until regional developments, such as a possible U.S.-led invasion of Iraq, became clearer. The eighth joint security meeting of the Turkey-Iran Commission on Security Cooperation, held in 
ÖZcan / ÖZdAMar: Turkish-Iranian ReLations since the 1979 Islamic ReVolution

October 2001, resulted in assurances from Iran that it would prevent the PKK from launching attacks into Turkey. Turkey also promised to cease political support for the National Liberation Movement of South Azerbaijan, an organization operating in the state of Azerbaijan. Iran's domestic political struggle between reformist President Khatemi and conservatives also contributed to Tehran's willingness to decrease tensions with its neighbors. ${ }^{52}$

The Great Rapprochement, 2003 Onward

In November 2002, an Islamist party

in Turkey won enough votes to form a government without a coalition partner for the first time in history. Justice and Development Party (AKP) governments have continued to rule Turkey since then, changing the course of Turkey's foreign policy, as well as its relations with Iran. In its first three years, the AKP government focused on improving relations with the European Union and, to some extent, with the United States. The AKP, whose leaders were members of the former Islamist RP (Welfare Party), sought international recognition and legitimacy. Therefore, the AKP focused on improving relations with Western countries in order to consolidate its position both at home and abroad. During this period, the AKP gained control of foreign-policy making in Turkey by strengthening its authority over the Ministry of Foreign Affairs, the TAF, and various bureaucratic institutions, as well as public opinion. The backbone of post-2005 Turkish foreign policy was built during this period. The relationship with Iran was not at the top of the AKP's foreign-policy agenda during 2003-05.

In this period, Iran's most important foreign-policy concern was the changing global and regional fallout from the
September 11 attacks in the United States. The general perception has been that Iran became more aggressive post-9/11 in its dealings with the Middle East and the United States. Iran continued to support Palestinian groups and Hezbollah with weapons and built up its nuclear program and missile systems. It also increased its presence in post-invasion Iraq, maintained its alliance with Syria, and cooperated with Shia cleric Moqtada al-Sadr's Mahdi army and other insurgent groups in Iraq. ${ }^{53}$ Many analysts have linked Iran's policies with the country's increasing perception of isolation and containment by the United States and its allies.

These regional and domestic developments provided a conducive environment for the rapprochement between Iran and Turkey. The interests of the two countries overlapped to a great extent in this period, largely due to the American-led invasion of Iraq. Both the governments and the publics in Iran and Turkey were strongly opposed to the invasion of Iraq. Turkey went against its long-term U.S. ally in March 2003, when parliament did not endorse joining the war. For both Iran and Turkey, the American invasion meant being less able to exert influence over Iraq and domestic clients such as the Kurdish and Shia groups. In addition, due to their own domestic Kurdish populations, Iran and Turkey have been wary of the disintegration of Iraq and the rise of an independent Kurdistan. Islamism has also contributed to the rapprochement between the two countries. ${ }^{54}$

Economic factors played a role in both countries' increased interest in better relations. AKP foreign policy included the spreading of Turkey's influence through its economic power as a "trading state." 55 Iran's economic capacity, its large do- 
Middle East Policy, Vol. XVII, No. 3, Fall 2010

mestic market and its energy resources meshed with this aim. On the other hand, Iran perceived Turkey as a "black knight" in the event that the United Sates and the UN Security Council (UNSC) imposed economic sanctions. To break its economic and political isolation, Iran found support from Turkey, a NATO member and EU candidate and therefor a valuable asset for its foreign-policy aims. Finally, growing dissent in Iranian Kurdistan led Tehran to cease support for PKK activities against Turkey, effectively weakening the Turkish foreign-policy elite's security-oriented perspective and the TAF's traditionally cautious attitude toward Iran.

In the post-2005 period, a growing disappointment with the course of the EU-membership negotiations led Ankara to further develop its relations with Middle Eastern states. The negotiations have been effectively blocked by the Cyprus issue and Franco-German opposition to Turkey. This led the AKP's more conservative Islamist wing to increase its influence in foreign affairs. Particularly after Prime Minister Erdoğan's former adviser, Professor Ahmet Davutoğlu, was appointed minister of foreign affairs, the Turkish foreign-policy focus on Muslim nations in the Middle East gained new momentum. Turkey not only improved its relations with Iran and Syria in various areas; it disagreed with Israel and the United States on issues such as Israel's military operations in Lebanon and Gaza. Since 2007, Turkey has been supportive of Iran's nuclear program as long as it is used for peaceful purposes. Bilateral trade has risen to unprecedented levels, new energy-transportation deals have been made and others are being negotiated.

There has also been some military cooperation to fight the PKK. Diplomatic visits and friendly relations have burgeoned.
The rapprochement between Turkey and Iran since 2002 may seem puzzling, given their historical rivalry. We argue, however, that the two decided to cooperate due to the changes and challenges caused by superpower penetration into the region since $9 / 11$. They have made common cause in order to resist superpower policies and other alliances. To resist superpower penetration into the region by means of the Afghan and Iraq wars, the two regional powers decided to cooperate. Turkey and Iran have attempted to counterbalance the United States, especially regarding the future of Iraq, the Kurds in the region and the Palestinian question. Turkey and Iran have stated their opposition to dismembering Iraq and creating an independent Kurdish state, thereby shaping the policy options of both Washington and Baghdad. Iran has continued its support for groups such as Hezbollah and Hamas, and Turkey mediated Syrian-Israeli and Israeli-Hamas relations until December 2008. After Operation Cast Lead, Turkey's criticism of Israel's policies in the Gaza Strip rose to an unprecedented level. Ankara has also criticized Israel's nuclear arsenal and U.S. tacit approval of it. All these developments approximated Turkish and Iranian foreign policies in the Middle East together. In spring 2010, after Turkey voted against sanctions on Iran at the UNSC and the flotilla crisis ${ }^{56}$ occurred between Israel and Turkey, it seemed as if Middle East politics was determined by Turkey's and Iran's counterbalancing of the U.S.-Israeli alliance.

\section{THE FUTURE}

Relations between Iran and Turkey will focus on three areas in the near future: economic relations, political/regional concerns and the nuclear issue. An initial 
ÖZcan / ÖZdamar: Turkish-Iranian ReLations since the 1979 Islamic ReVolution

thaw in economic relations occurred in 1996, gaining momentum since 2002. Despite both countries' enormous potentials, their trade volume did not even exceed $\$ 1$ billion during the 1990s. ${ }^{57}$ This was due to serious political and security problems. After Turkey and Iran began to settle their differences regarding the PKK, the Mujahedin el-Khalq and Iraq, however, economic relations began to improve. A first step was Turkish President Ahmet Sezer's visit to Tehran in 2002, following the post2001 collapse of the Turkish economy and new developments in the political relations of the two countries. In 2002, bilateral trade amounted to $\$ 1.2$ billion; $; 8$ in 2009 , it surpassed $\$ 10$ billion. In March 2009, Turkey and Iran signed a memorandum of understanding to improve land, sea and air transportation in order to increase the trade volume to $\$ 20$ billion. ${ }^{59}$ Iran's first vice president, Mohammed-Reza Rahimi, announced that the Turkey-Iran trade volume reached $\$ 11$ billion in 2009. Rahimi added that Iran desired to increase this number to $\$ 30$ billion in the next five years. ${ }^{60}$

Turkey's increasing trade volume and economic ties with its neighbors have been mainstays of its foreign policy during the AKP years. Turkey is more industrialized than surrounding countries, and AKP policy makers aim to turn this into an advantage in foreign affairs. Therefore, exporting manufactured goods and services to Iran in return for gas and oil appears to be a beneficial policy. On the other hand, improving economic ties with Turkey also has political consequences for Iran, as Turkey has preferred to improve economic relations in spite of $\mathrm{UN}$ sanctions. Turkey has already defied warnings by the United States not to further improve gastransportation deals with Iran, Turkey's second-largest natural-gas supplier. The first pipeline agreement between the two was signed in 1996. Today, Turkey buys 15 percent of its LNG (liquefied natural gas) from Iran. Since 2008, the two countries have been negotiating deals to improve cooperation and the construction of pipelines that would transport Iranian gas to European markets. The Nabucco project, which will transport Caspian gas to eastern and central European markets to decrease Europe's dependency on Russian gas, is likely to be at the center of discussions in the near future. In case Azerbaijan's gas supplies prove inadequate, Turkey and Iran propose gas exports from Iran to European markets via Turkey. The United States and some EU members oppose the inclusion of Iranian gas for political reasons. The AKP government is likely to side with Iran on this matter if the latter's involvement in Nabucco proves necessary in the future.

The most important regional issue will continue to be Iraq and the Kurds. Since the 2003 invasion of Iraq by a U.S.-led coalition, Turkish and Iranian opinions have converged, and this trend is likely to continue in the near future, particularly regarding the territorial unity of Iraq. If Turkish-Iranian security cooperation against the PKK is maintained, Turkey will be more likely to cooperate with Iran on other matters as well. However, the Kurdish issue is only of secondary interest to Iran. Iran's major concern is its relationship with the United States. If Iran-U.S. relations deteriorate, Iran could destabilize Iraq to a great extent.

Regarding other issues involving Iraq, however, Turkey and Iran may find themselves at odds. If the Shia-Sunni rift becomes unmanageable, the AKP government is more likely to side with Iraqi Sunnis, while Iran will support the Shia. Turkey has also built good relations with 
Middle East Policy, Vol. XVII, No. 3, Fall 2010

Sunni Arab countries in the Gulf over the past years, and this would affect its policies towards further Sunni-Shia conflict.

Iran's nuclear program and Turkey's attitude towards it are likely to be the greatest challenges in the near future. Developments in 2008-09 confirmed that Iran has advanced its nuclear program and the possibility that it could produce a nuclear bomb in the future. ${ }^{61}$ The Obama administration's "engagement policy" has failed to bring about a diplomatic solution to the problem, and sanctions against Iran were passed at the UNSC in May 2010.

Prime Minister Erdoğan and the AKP leadership have been defending Iran's right to develop peaceful nuclear technology in the last few years, even offering to mediate between Iran and the West. The Turkish prime minister repeatedly stated that Turkey is against nuclear proliferation in the region; yet, the government believes Iran's nuclear technology is "solely for peaceful purposes." ${ }^{62}$ The Turkish government has also referred to Israel's nuclear program and argued for a nuclear-free Middle East. The Erdoğan government's policies against Israel reflect the AKP's ideological stance as much as its interestbased foreign policy. ${ }^{63}$ As a non-permanent member of the UNSC, the Turkish government voted against the sanctions on Iran in May 2010. Emphasizing the importance of the nuclear-swapping agreement brokered by Turkey and Brazil earlier that month, Turkey claimed sanctions will not resolve the Iranian nuclear issue.

The AKP government has faced international pressures for voting against sanctions at the UNSC, as Turkey is a NATO member, a long-term ally of the United States and a candidate for EU membership. Siding with Iran on the nuclear issue and the crisis with Israel has increased pres- sure on the AKP government to a great degree, and within the party, there is a debate about the future of Turkish foreign policy. As general elections will be held in 2011, Erdoğan has to address criticisms of his government's foreign policy and relations with Iran. If he takes a pragmatic stance for his political survival, a revision of Turkey's foreign policy both on Iran and the Middle East might be expected. If AKP loses the elections, a new government is less likely to maintain its pro-Iran policy.

\section{CONCLUSION}

There is an inherent structural rivalry between Turkey and Iran. Cultural, geographic, political, ideological and economic factors are the constants that have shaped their relationship. Iran and Turkey have competed for leadership of the Muslim world since the early modern ages and persist even today, although at a regional level. However, a rapprochement between the two has been observed in the last decade to balance the increased American penetration into the region.

The invasion of Iraq and the subsequent failure of the U.S.-led coalition to fully control the country have induced a thaw in Turkey-Iran relations and shaped their cooperation. Both countries are on the same page concerning the future of the Kurdish autonomous region and the territorial integrity of Iraq, although Turkey's worries about the Kurds are greater than Iran's. A pragmatic cooperation against the PKK has been achieved. Iran and Turkey also support Palestinian movements and have been critical of Israel's policies in Lebanon and Gaza. Both countries are wary of Kurdish movements in the region and, if cooperation concerning the PKK and other groups can be maintained, Turkey will be more likely to collaborate 
with Iran on other matters as well. Sectarian conflict in Iraq may also shape the two countries' relations; they may find themselves supporting opposing factions. The political rapprochement, however, is strengthened by bilateral economic deals that are useful to both economies.

Finally, domestic political factors will be important for the future of the relationship. Iran has been destabilized since the
June 2009 elections and the protests that followed. A weakened regime could turn to domestic affairs rather than focusing on foreign relations; in Turkey, if the AKP loses the elections in 2011, the new government may not be so pro-Iran. Only time will tell what turns the structural rivalry and recent rapprochement between Turkey and Iran will take.

${ }^{1}$ İzetullah İzzeti, İran ve Bölge Jeopolitiği (İstanbul: Küre Yayınları, 2005).

${ }^{2}$ Çağrı Erhan and Mustafa Aydın, eds., Beş Deniz Havzasında Türkiye (Ankara, Siyasal Kitabevi, 2008).

${ }^{3}$ Gökhan Çetinsaya, "Essential Friends and Natural Enemies: The Historic Roots of Turkish-Iranian Relations," Middle East Review of International Affairs, Vol. 7, No. 3, Sept. 2003.

${ }^{4}$ CIA World Factbook. https://www.cia.gov/library/publications/the-world-factbook/index.html.

For more information on the influence of Azeri ethnic groups on Iranian politics in the post-1945 era, see Cemil Hasanlı, Soğuk Savaşın İlk Çatışması İran Azerbaycanı (İstanbul: Bağlam Yayıncılık, 2005).

${ }^{5}$ For more information on the effect of Turkic dynasties in Iran's history, see Y1lmaz Karadeniz, Iran'da Sömürgecilik Mücadelesi ve Kaçar Hanedanı (1795-1925), (İstanbul: Bakış Yayınları 2006).

${ }^{6}$ Enver Ziya Karal. Osmanlı Tarihi VII. Cilt: Birinci Meşrutiyet ve Istibdat Devirleri (1876-1907), (Ankara:

Türk Tarih Kurumu Basımevi. 3. Basım. 1988), pp. 126-146.

${ }^{7}$ Halil İnalcık, Osmanlı İmparatorluğu: Toplum ve Ekonomi (İstanbul: Eren Yayıncılık, 1993), pp. 167-179.

${ }^{8}$ Karal, op.cit.

${ }^{9}$ Hüsrev Gerede, Siyasi Hatıralarım I: Íran 1930-1934 (İstanbul, Vakit Basımevi, 1952).

${ }^{10}$ Korgeneral Metin Sağlam, Iran'da Monarşiden İslam Cumhuriyeti’ne Geçiş ve Türkiye'ye Etkileri (İstanbul: Harp Akademileri Basım Evi. 1997).

11 “Öztrak Doğu'da Şah Yanlısı İran Ordusu Kurulduğu Haberlerini Yalanladı," Cumhuriyet (Turkish Daily Newspaper), December 29, 1981; and “Türkiye'deki İranlıların Sayıs1 600 bin ile 1 milyon arasında," Milliyet (Turkish Daily Newspaper), October 20, 1986.

${ }^{12}$ For example, the Iranian media targeted President Evren of Turkey, who took over power after the 1980 coup, and the Turkish Armed Forces frequently. These news reports were protested by Turkish counterparts. Kenan Evren, Kenan Evren'in Anıları 6 (İstanbul, Milliyet Yayınları, 1992), pp. 127-131.

${ }^{13}$ For more information on post-1639 Iran-Turkey border problems and agreements, see Mehmed Hurşid Paşa, Seyahatname-i Hudud. (İstanbul, Simurg Yayıncılık, 1997).

${ }^{14}$ For the role of Iran during the Kurdish rebellions during 1924-1938, see T.C. Genelkurmay, Harp Tarihi Başkanlığı Resmi Yayınları Seri No. 8. Türkiye Cumhuriyetinde Ayaklanmalar: 1924-1938 (Ankara: Genelkurmay Basimevi, 1972).

${ }^{15}$ Gerede, op.cit., pp. 193-198; Rohat Alakom, Hoybun Örgütü ve Ağrı Ayaklanması (İstanbul: Avesta Yayınevi, 1998; and Eyüp Sabri Süsoy, Eşkıya Muharebeleri ve Mă̆ara Aramaları (Genelkurmay Başkanlığ X. Şube, İstanbul: Askeri Matbaa, 1944).

${ }^{16}$ Peter Hopkirk, On Secret Service East of Constantinople (Oxford Paperbacks, 2001).

${ }^{17}$ Çetinsaya, op.cit., For more information on Iran's support for various Armenian rebellions, see Justin McCarthy, Esat Arslan, Cemalettin Taşkıran and Ömer Turan, The Armenian Rebellion at Van (University of Utah Press, 2006).

${ }^{18}$ Shahram Chubin, "Iran," in Yezid Sayigh and Avi Shlaim, eds., The Cold War and the Middle East (Clarendon Press, 1997). 
Middle East Policy, Vol. XVII, No. 3, Fall 2010

${ }^{19}$ Erhan and Aydın, op.cit.

${ }^{20}$ Nihat Ali Özcan and Özgür Özdamar, "Iran's Nuclear Program and Future of U.S.-Iranian Relations," Middle East Policy, Vol. 16, No. 1, 2009, pp. 121-133.

${ }^{21}$ Bülent Aras and Fatih Özbay, "The Limits of Russian-Iranian Strategic Alliance: Its History and Geopolitics, and the Nuclear Issue," Korean Journal of Defense Analysis, Vol. 20, No.1, Winter 2008, pp. 47-62. ${ }^{22}$ Nihat Ali Özcan, PKK Tarihi, İdeolojisi ve Yöntemi (Ankara: ASAM Yayınları, 1999), pp.222-43.

${ }^{23}$ See the memoirs of Hashimi Muhteshemi, Iran's former ambassador to Damascus: Haşimi Muhteşemi, "İran Eski Şam Büyükelçisi Huccetilislam Haşimi Muhteşemi’nin Suriye ve Lübnan Anıları," Dünya ve Íslam, Say1 4, Güz 1990.

${ }^{24}$ Hussein J. Agha and Ahmad S. Khalidi, Syria and Iran: Rivalry and Cooperation (London, Royal Institute of International Affairs, 1995);

Ofra Bengio, The Turkish-Israeli Relationship: Changing Ties of Middle Eastern Outsiders (Palgrave, 2004); and Meliha B. Altunışık, "Güvenlik Kıskacında Türkiye-Ortadoğu İlişkileri," in Gencer Özcan and Şule Kut, eds., En Uzun Onyıl (İstanbul, Boyut Matbaac1lık, 1998).

${ }^{25}$ Erhan and Aydin, op.cit.

${ }^{26}$ Özgür Özdamar and Zeynep Taydaş. "Foreign Policy, Public Opinion and the Iraq War: The Turkish Case," in Richard Sobel, Bethany Barratt and Peter Furia, eds., Public Opinion and International Intervention: Lessons from the Iraq War (Potomac Books, 2010).

${ }^{27}$ Turgut Tülümen, Iran Devrimi Hatıraları (İstanbul: Boğaziçi Yayınları, 1998).

${ }^{28}$ Çetinsaya, op.cit.

${ }^{29}$ The developments in the east raised worries in Ankara. Immediately after the revolution, the TAF moved its second army's headquarters from Konya (central Turkey) to Malatya (in eastern Turkey) during early 1980s. See T.C. Karakuvvetleri, Komutanlığı 2nci Ordu Komutanlığı Malatya. 2. Ordu Tarihçesi: $1843-1996$ (Malatya: 2nci Ordu Matbaas1, 1996) s. 4/17-18).

${ }^{30}$ Tülümen, op.cit.

${ }^{31}$ TÜSİAD (Turkish Businessman and Industrialists' Association), “Turkey’s Policy towards Neighboring and Surrounding Countries within the Accession Process to the European Union," May 2007.

32 This neutrality policy was so strict that Turkey announced it would not allow the United States to use T1urkish bases against Iran (“Savunma Bakanı: ABD’ye İran'a Müdahele için İncirlik’i kullanma izni vermeyeceğimizi belirttik," Cumhuriyet, February 5,1980).

${ }^{33}$ Iranian officials repeatedly condemned Turkey's operations in Northern Iraq and announced their worries ('İran Başbakanı Musavi: Irak’ın Kuzeyindeki Olayları İzliyoruz”, Cumhuriyet, February 5, 1980; “İran'la İlişkilerde Pürüz", Cumhuriyet August 23, 1986).

${ }^{34}$ Tülümen, op.cit.

35 “İran’da Halefoğlu'nun Ziyareti Öncesinde Çirkin Tavır: Atatürk’e Dil Uzattılar,” Hürriyet, Tülümen, op.cit.," August 26, 1986.

${ }^{36}$ Tülümen, op.cit.

${ }^{37}$ Muhteshemi', op.cit.

${ }^{38}$ Shireen Hunter, "Turkey, Central Asia, and the Caucasus: Ten Years After Independence," Southeast Europe and Black Sea Studies, Vol. 1, No. 2, May 2001, pp.1-16.

${ }^{39}$ Ibid.

${ }^{40}$ Interview with a top TAF commander who worked in the region at the time of incident.

${ }^{41}$ Michael M. Gunter, “Turkey and Iran Face Off in Kurdistan,” Middle East Quarterly, March 1998.

42 Ibid.

${ }^{43}$ Tülümen, op.cit

44 Ibid.

${ }^{45}$ Robert Olson. "Turkey-Iran Relations, 1997 to 2000: The Kurdish and Islamist Questions," Third World Quarterly, Vol. 21, No. 5, 2000., p. 877.

${ }^{46}$ For relations between Iran and Kurdish Hezbollah in Turkey, see Emniyet Genel Müdürlüğü, Hizbullah Terör Örgütü (Ankara: EMÜH Daire Başkanlığı Yayınları No. 8. 2001). The Iranian Revolution and the mullah regime established in its aftermath were perceived differently by various segments of society in Turkey. For example, to understand secularist TAF's perceptions, see Korgeneral Metin Sağlam, Iran'da Monarşiden İslam Cumhuriyeti’ne Geçiş ve Türkiye’ye Etkileri (İstanbul: Harp Akademileri Basım Evi, 1997). For Turk- 
ÖZCan / Özdamar: TuRKish-Iranian Relations since the 1979 Islamic Revolution

ish Islamists' perceptions of the new regime in Iran, see İslami Ilimler Araştırma Vakfi adina 14-30 Eylül 1991 Tarihleri Arasında Iran'a Yapılan Inceleme Gezisi Hakkında Rapor (İstanbul: Objektif Yayınları, 1992) , 2 bask1).

${ }^{47}$ Tülümen, op.cit.

${ }^{48}$ Ibid.

${ }^{49}$ Olson, p. 876.

${ }^{50}$ Ibid.

${ }^{51}$ Robert Olson. “Turkey-Iran Relations, 2000-2001," Middle East Policy, Vol. 9, No. 2, June 2002.

${ }^{52}$ Ibid.

${ }^{53}$ Mark Gasiorowski, “The New Aggressiveness in Iran's Foreign Policy,” Middle East Policy, Vol. 14, No, 2, Summer 2007, pp. 125-32.

${ }^{54}$ Meliha Altunışık, "Worldviews and Turkish Foreign Policy in the Middle East," Special Issue on Turkish Foreign Policy, New Perspectives on Turkey, Vol. 40, 2009, pp. 169-92.

${ }^{55}$ Kemal Kirşiçi, "The Transformation of Turkish Foreign Policy: The Rise of the Trading State," New Perspectives on Turkey, Vol. 40, 2009, pp. 29-56.

${ }^{56}$ On May 31, 2010, Israeli Defense Forces (IDF) raided an aid organization flotilla bound for the Gaza Strip. Eight Turkish and one U.S. citizen of Turkish origin were killed by the IDF. The Turkish government suggested the flotilla carried humanitarian aid while the Israeli government claimed the IHH, the organization that organized the aid flotilla, had connections with Hamas. The period after the flotilla crisis witnessed the worst Turkish-Israeli relations since they began in 1949.

${ }^{57}$ TÜSİAD.

${ }^{58}$ Ibid.

59 “Turkey, Iran Sign Memorandum of Understanding on Transportation," Turkey Daily News. Mar, 2, 2009, at http://www.turkeydailynews.com/news/118/ARTICLE/1635/2009-03-02.html.

60 "VP: Iran-Turkey Trade Exchange to Increase to 30 Billion Dollars," Islamic Republic News Agency, Oct. 27, 2009, http://www.irna.ir/En/View/FullStory/?NewsId=757194\&idLanguage=3.

${ }^{61}$ Özcan and Özdamar, op.cit.

${ }^{62}$ BBC News. "Iran Nuclear Programme Solely Civilian - Turkish PM," BBC News, March 16, 2010, http:// news.bbc.co.uk $/ 2 / \mathrm{hi} / \mathrm{middle}$ east $/ 8570842 . \mathrm{stm}$.

${ }^{63}$ Tarik Oğuzlu, "Middle Easternization of Turkey's Foreign Policy: Does Turkey Dissociate from the West?" Turkish Studies, Vol. 9, No. 1, March 2008. 